\title{
Static Fire Danger Estimation Based on the Historical MODIS Hotspot Data Using Geospatial Techniques for the Uttarakhand State, India
}

\author{
K. V. S. Babu ${ }^{*}$ and A. Roy ${ }^{2}$ \\ ${ }^{1}$ International Institute of Information Technology, Hyderabad \& Indian Institute of Remote Sensing, ISRO, Dehradun 248001, India \\ ${ }^{2}$ Disaster Management Sciences, Indian Institute of Remote Sensing, ISRO, Dehradun 248001, India.
}

Received 15 July 2020; revised 01 October 2020; accepted 02 October 2020; published online 02 October 2020

\begin{abstract}
Forest fires are more frequent in Uttarakhand state, especially during the months from March to June each year, causing a major impact on forest resources, wildlife habitats, economic and environment. The essential factors favourable to fire dan ger are the ignition factors and spreading factors. Ignition factors are either natural or androgenic activities; spreading factors are type of vegetation, topographic properties and terrain characteristics and dynamic weather variables such as temperature, relative humidity and precipitation. Vegetation, topographic and terrain conditions are static, whereas the dynamic variables change more frequently in a day. In this study, Static Fire danger Index (SFDI) has been developed from the MODIS TERRA, AQUA and ASTER datasets namely, MODIS Land cover type yearly L3 global $500 \mathrm{~m}$ SIN grid (MCD12Q1) and ASTER GDEM. LULC danger index, Slope danger index, Aspect danger index, Elevation danger index and Terrain ruggedness danger Index have been generated from the above datasets based on the historical fire data and field observation. The SFDI has been generated by integrating the above-mentioned indices and categorized into 5 fire danger classes from no fire to very high. The results were compared with the MODIS active fire product (MCD14) and the accuracy of SFDI is 90\%, 95.9\% and 92.5\% for the years 2015, 2016 and 2017 respectively. The SFDI is generated each year with updated MODIS land cover type product with a spatial resolution of $1 \mathrm{~km}$ and is useful to understand the spatial pattern of fire occurrence and also determine areas of high fire danger due to the static ignition factors.
\end{abstract}

Keywords: Static Fire Danger Index, MODIS, MCD12Q1, forest fire, ASTER GDEM

\section{Introduction}

Forest fires caused extensive damage to the forest resources, environment, humans and property across the world. Uttarakhand forests in India are prone to forest fires, causing loss of biodiversity and degradation of the environment (Pyne et al., 1996; Cochrane, 2003). Most of the valuable plant and animal species are depleted due to the frequent occurrence of forest fires (Mukhopadhyay, 2001).

For forest fires to occur, the presence of factors conducive to forest fire occurrence is essential. The conditions conducive to forest fire risk and be broadly categorized into two types. The two types of factors i.e. ignition factors and spreading factors responsible for initializing and spread of forest fires. Forest fires are initiated either naturally or by anthropogenic activities (Negi, 1986). Most of the forest fires are due to human activities i.e. intentional and unintentional. Three main factors are considered to be responsible for the spread of forest fires: the first factor is the vegetation cover, which includes the type of forest, fine fuel moisture content and inflammability of fuel (Ye et al.,

*Corresponding author. Tel.: +91-7895208605.

E-mail address: sureshbabu.iiith@gmail.com (K. V. S. Babu).

ISSN: 2663-6859 print/2663-6867 online

(C) 2020 ISEIS All rights reserved. doi:10.3808/jeil.202000038.
2017). Topography is an important parameter, wherein slope, aspect and elevation play a major role in spread of forest fire (Kushla and Ripple, 1997; Butler et al., 2007). Final factor is Weather, which is a dynamic factor and influences fire ignition and spread involve parameters like relative humidity, air temperature, wind speed and rainfall (Roberto Barbosa et al., 2010). Fuel and topography factors are static in nature, does not change over longer time periods where as the weather factor is dynamic, changes frequently over short span of time.

There is a strong relationship between the vegetation type and forest fire intensity and frequency as each vegetation type has a different fire proneness due to the flammability of vegetation (Raison, 2005). In general, coniferous forests are more prone to fires than deciduous forests, because of the lesser moisture content and higher resin/oil content in coniferous vegetation (Hély et al., 2000). Fuel is an important parameter because it influences the ignition potential as well as the intensity of forest fire (Pyne et al., 1996). The state and type of the fuel describe the characteristic of forest fires. Fuel can be either living organic material like grass, shrubs, trees or dead material like fallen branches, leaves, needles, twigs etc. and the size, moisture content, chemical composition influences the fire behavior and intensity (Whelan, 1995).

Topographical features such as slope, aspect, elevation can influence the fire spread and behavior. Generally, fire travels up 
the slope as compared to down the slope and influences rapid increase the fire spread (Kushla et al., 1997; Butlet et al., 2007; Babu et al., 2016b). Steepness of the slope influences the intensity of solar radiation and fuel moisture and also influences the rate of fire spread. Aspect represents the direction of the slope, and based on the northern or southern hemisphere determines the amount of solar radiation and the type of vegetation present (Kushla et al., 1997; Butlet et al., 2007; Babu et al., 2016b). In the northern hemisphere, southern slopes receive more solar radiation as compared to the northern slopes so vegetation starts to dry by February-March in the slopes of the southern aspect and are highly dried up during the summer season. In contrast, slopes in the northern aspect are cooler and moist so drying up the vegetation is relatively slower (Måren et al., 2015). Elevation influences the amount of precipitation as well as the wind speed and therefore it affects the fire behavior (Babu et al., 2016 b). Elevation also affects the drying period of the vegetation. In lower elevations, vegetation tends to dry out sooner as compared to the higher elevations due to higher temperatures and lower precipitation in the lower elevations (Wimberly et al., 2009).

Fire danger rating systems are important tools for the management of fire activities such as forecasting the fire danger maps on the basis of static and dynamic parameters (Babu et al., 2019). The Fire Danger Rating System is a Decision Support System, which takes into consideration of all the factors affecting the fire danger such as fuel type, weather parameters and terrain characteristics and indexing into different classes of fire danger from no danger to extreme danger based on the value for the purpose of issuing warnings to the public, implementing the mitigation measures for controlling fires (Babu et al., 2019). The most common fire danger rating systems are Canadian Fire Danger System (Van Wagner and Forest, 1987), Australia's McArthur Forest Fire Danger Index (McArthur, 1967), US National Fire Danger Rating System (Deeming, 1977), and European Forest Fire Information System (Vilar et al., 2015). The Fire Danger Rating system is an integration of dynamic and static fire danger rating indices. Dynamic fire danger rating index is based on weather parameters such as air temperature, relative humidity, wind speed and rainfall while Static fire danger index is based on the constant parameters such as fuel characteristics, topographic conditions (Babu and Roy, 2019). In this study, we have developed the static fire danger index as it gives the probability of fire distribution in the study area. Static fire danger index has been calculated from the constant parameters such as fuel characteristics, topographic conditions in this study. Till now, there is no studies available on the static fire danger indices except the fire risk zonation studies.

\section{Data Source and Study Area}

\subsection{Data Source}

The Static Fire Danger Index (SFDI) was generated from the MODIS land cover type product (MCD12Q1) and ASTER GDEM datasets, which were downloaded from the NASA Earth data website (https://earthdata.nasa.gov/). The Moderate Resolution Imaging Spectroradiometer (MODIS) is a sensor on board NASA TERRA and AQUA satellites since 1999 and 2002 respectively. The MCD12Q1 is a global land cover annual product of $500 \mathrm{~m}$ spatial resolution, it provides the five land cover schemes i.e. IGBP global vegetation classification scheme; University of Maryland scheme; Leaf Area Index / fraction of photosynthetically active radiation (LAI/FPAR) scheme; Net Primary Production scheme (NPP) and Plant Functional Type (PFT) scheme (LPDAAC website). The IGBP classified scheme is the primary land cover scheme and it consists of 17 land cover types (Belward et al., 1999; Friedl et al., 2010). The MODIS product MCD12Q1 during the years from 2001 to 2014, were downloaded from the Earth Explorer website. Advanced Spaceborne Thermal Emission and Reflection Radiometer Global Digital Elevation Model Version 2 (ASTER GDEM V2) product was developed by the NASA \& Japan Ministry of Economy, this can be downloaded from the Earth data website (https://earthdata.nasa.gov/). The MCD14 provides the thermal anomaly and fire location information, which can be derived from the MODIS $4 \mu \mathrm{m}$ and $11 \mu \mathrm{m}$ radiances. The MCD14 data have been downloaded from the Fire Information for Resource Management System (FIRMS) website (https://firms.modaps. eosdis.nasa.gov/).

\subsection{Study Area}

The study area is Uttarakhand state, hill state in India, which shares an international border with China in the north and $\mathrm{Ne}$ pal in the east. Uttarakhand lies between $28^{\circ} 43^{\prime \prime} \mathrm{N}$ to $31^{\circ} 27^{\prime \prime} \mathrm{N}$ latitude and $77^{\circ} 34^{\prime \prime} \mathrm{E}$ to $81^{\circ} 02^{\prime \prime} \mathrm{E}$ longitude. The location of the study area is shown in Figure 1.

Uttarakhand state is largely a rocky mountainous region, where the altitudes dramatically fluctuate between $300 \mathrm{~m}$ to 7817 $\mathrm{m}$. The large variations in altitudes, the slope, aspect, presence of glaciers, forests, and its geographical locations has resulted in varying climates in different parts of Uttarakhand state, even at the micro or local levels. There are four major forest types distributed in this state, which include the Alpine meadows in the higher elevation above treeline, Temperate forest in the Himalaya ranges, Tropical deciduous forests in the lesser Himalaya and mixed deciduous and thorny vegetation in the Shiwalik range and in some parts of the Terai. Forest fire is a regular feature in Uttarakhand forest ecosystems and most valuable plant and animal species can be depleted due to the frequent incidences of forest fires (ISFR, 2011). More than 50\% of Himalayan forests in Uttarakhand are prone to high incidence of fire, during the months from March to June in every year (Babu et al., 2016b).

\section{Methods}

SFDI has been generated from the satellite datasets MCD12Q1 and ASTER GDEM datasets based on the historical fire hot spot (MCD14) data and Figure 2 shows the methodology adapted in this study.

\subsection{Historical Forest Fire Hotspot Data}

The MODIS TERRA and AQUA fire hotspot product MCD 


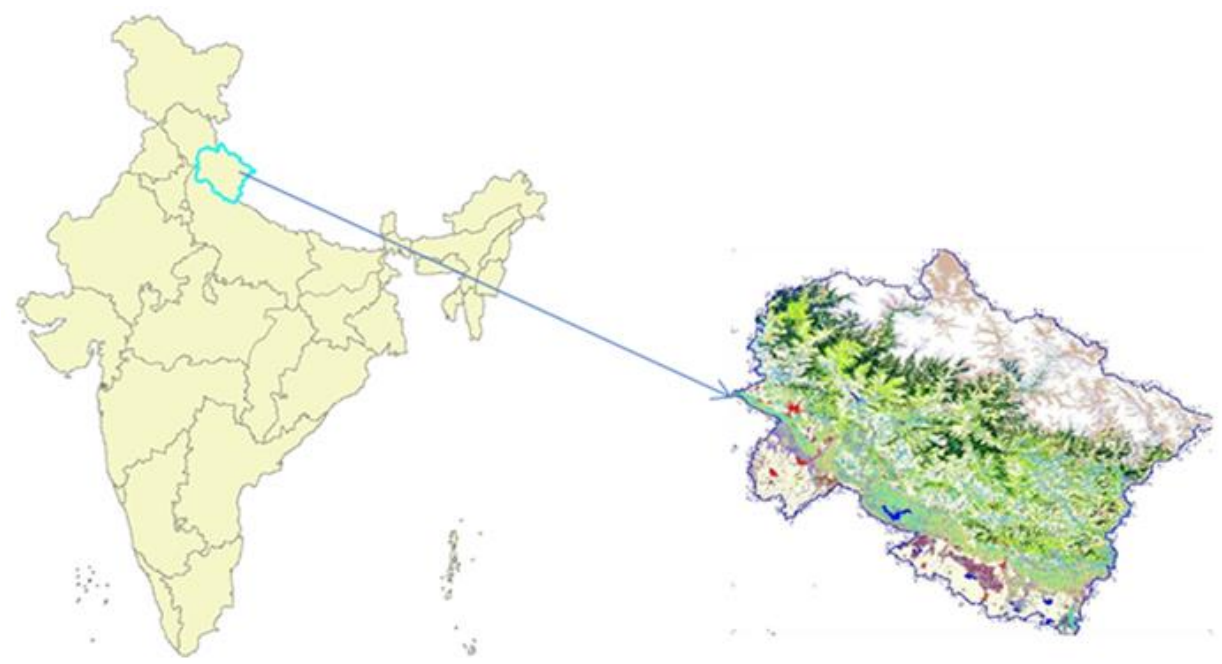

Figure 1. Location of the study area - Uttarakhand state, India.

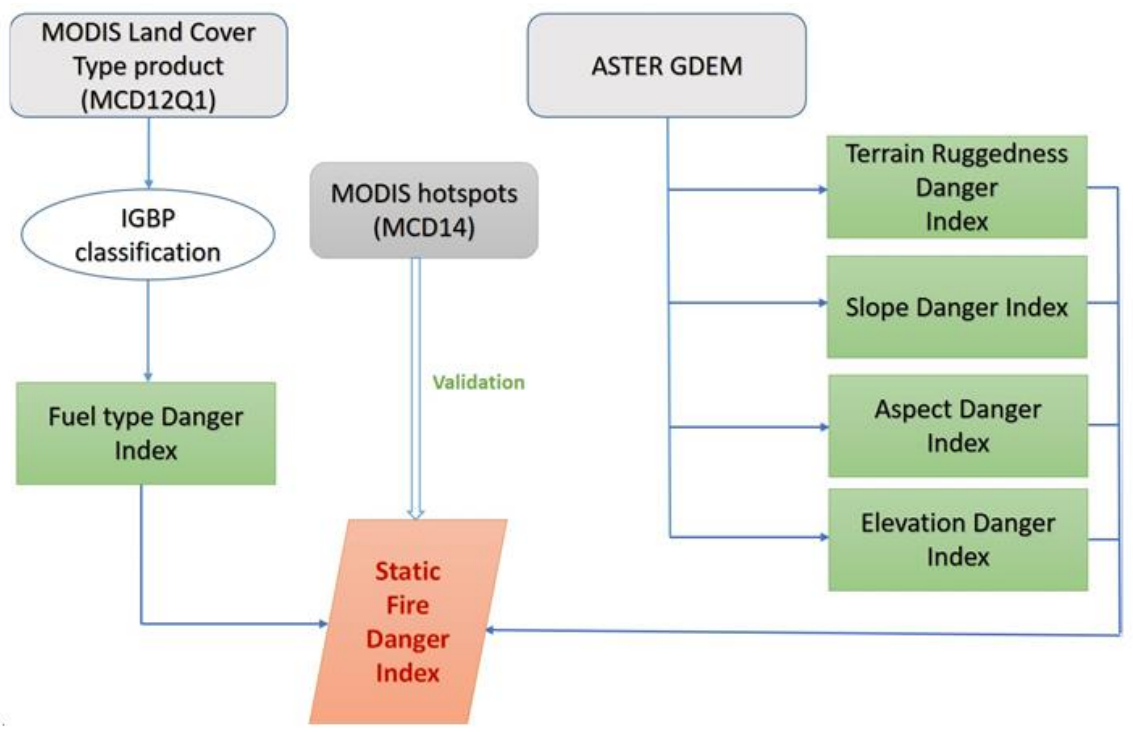

Figure 2. Flow chart showing the methodology.

Table 1. Description of Different Danger Levels

\begin{tabular}{llll}
\hline S. No & Normalized score $(\%)$ & Name of the danger level & Description \\
\hline 1 & $<=5$ & No fire & Un favorable conditions \\
2 & $5 \sim 10$ & Low & Possible chances of fire \\
3 & $11 \sim 15$ & Moderate & Quite possible chances of fire \\
4 & $16 \sim 20$ & High & More favorable \\
5 & $>20$ & Very high & Most favorable \\
\hline
\end{tabular}

14 were downloaded for the study area Uttarakhand from 2010 to 2014. The product consists of fire location information, date and time of acquisition, brightness temperature and Fire Radiative Power (FRP) on each day. Grey Relativity Analysis has been used to evaluate the weights of each factor, influencing the fire danger. This method is an effective technique to solve the uncertainty problems consists of distinct datasets with less information (Chan and Tong, 2007; Zhai et al., 2009; Gai et al., 2011).

\subsection{LULC Danger Index (LULCDI)}

The MODIS land cover type product (MCD12Q1) provides five global land cover classification systems and also provides a land cover type assessment, quality control information (LPDAAC). International Geosphere-Biosphere Programme (IGBP) land cover type has been generated from MCD12Q1 using HDF-EOS to GeoTiff conversion tool (HEG) software. The historical fire data were downloaded for the corresponding 
Table 2. Fire Incidents in Different Landcover Classes of IGBP Classification

\begin{tabular}{llllll}
\hline IGBP classes & 2010 & 2011 & 2012 & 2013 & 2014 \\
\hline Evergeen needleaf forest & 3 & 1 & 14 & 1 & 1 \\
Evergeen Broadleaf forest & 0 & 0 & 4 & 3 & 0 \\
Deciduous Needleleaf Forests & 0 & 0 & 0 & 0 & 0 \\
Deciduous Broadleaf Forests & 0 & 0 & 2 & 0 & 0 \\
Mixed Forests & 661 & 103 & 1378 & 180 & 757 \\
Closed Shrublands & 7 & 2 & 5 & 1 & 4 \\
Open Shrublands & 0 & 0 & 1 & 0 & 0 \\
Woody Savannas & 216 & 35 & 397 & 66 & 223 \\
Savannas & 0 & 0 & 0 & 0 & 2 \\
Grasslands & 19 & 6 & 49 & 10 & 1 \\
Permanent Wetlands & - & - & - & - & - \\
Cropland & 213 & 85 & 324 & 48 & 51 \\
Urban and Built-up & 9 & 0 & 4 & 5 & 4 \\
Cropland/Natural Vegetation Mosaics & 185 & 32 & 233 & 34 & 98 \\
\hline
\end{tabular}

Table 3. Fire Danger Level of Different Land Cover Types

\begin{tabular}{lll}
\hline IGBP classes & Normalized score (\%) & Danger level \\
\hline Evergeen needleaf forest & 0.31 & No danger \\
Evergeen Broadleaf forest & 0.21 & No danger \\
Deciduous Needleleaf Forests & 0 & No danger \\
Deciduous Broadleaf Forests & 0.02 & No danger \\
Mixed Forests & 52.92 & Very high \\
Closed Shrublands & 0.43 & No danger \\
Open Shrublands & 0.01 & No danger \\
Woody Savannas & 16.94 & High \\
Savannas & 0.04 & No danger \\
Grasslands & 1.74 & low \\
Permanent Wetlands & 0.00 & No danger \\
Cropland & 16.02 & high \\
Urban and Built-up & 0.53 & No danger \\
Cropland/Natural Vegetation Mosaics & 10.85 & Moderate \\
\hline
\end{tabular}

years (2010 2014) and these fires data were overlaid with the IGBP land cover type map to determine the type of land cover that are more vulnerable to fire. The percentage of fire incidents were calculated for each land cover type in each year so that the actual vulnerability of each land cover type has been determined during the fire season irrespective of the number of fire incidents. The mean of the percentages was calculated for the entire years and the danger levels were categorized into 5 types as shown in the Table 1.

Table 2 shows the number of fire incidents in different land-cover classes of IGBP classification for the years from 2010 to 2014.

Percentage of fires were calculated in each year and the normalized score i.e. mean of percentage of all the years were calculated for each landcover type and shown in the Table 3 and danger levels were assigned based on the Table 1. Figure 3 showing the LULC danger index.

\subsection{Terrain Ruggedness Danger Index (TRDI)}

Terrain heterogeneity is an important parameter for describing the species diversity in the mountainous area. Terrain

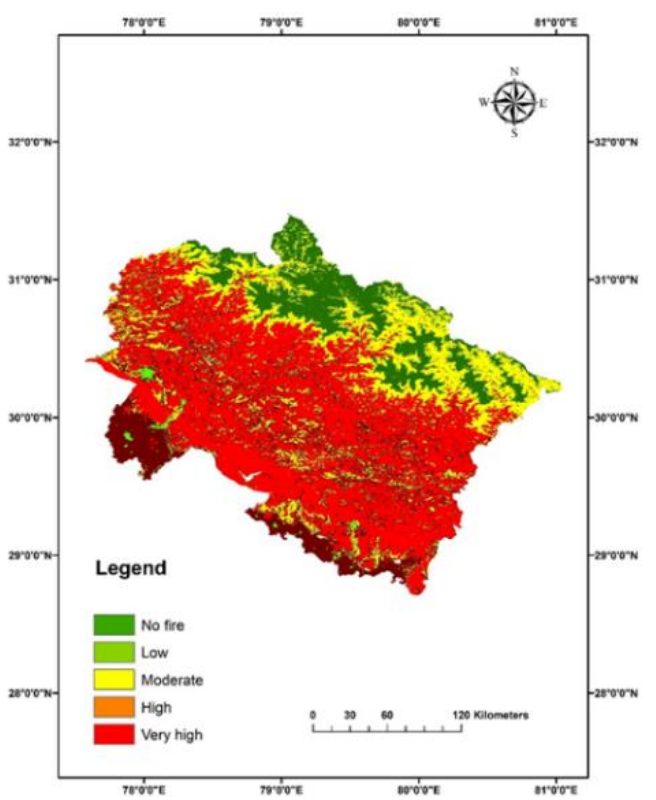

Figure 3. LULC danger index. 
Table 4. Fire Hotspots Occurred in Different TRI Class Levels

\begin{tabular}{|c|c|c|c|c|c|c|}
\hline TRI index & TRI class & Year & & & & \\
\hline & & 2010 & 2011 & 2012 & 2013 & 2014 \\
\hline $0 \sim 80$ & Level & 552 & 308 & 1607 & 201 & 853 \\
\hline $81 \sim 116$ & Nearly Level & 69 & 9 & 48 & 18 & 4 \\
\hline $117 \sim 161$ & Slightly Rugged & 97 & 6 & 22 & 12 & 7 \\
\hline $162 \sim 239$ & Intermediately Rugged & 167 & 36 & 365 & 47 & 72 \\
\hline $240 \sim 497$ & Moderately Rugged & 425 & 95 & 858 & 97 & 316 \\
\hline $498 \sim 958$ & Highly Rugged & 14 & 3 & 8 & 1 & 7 \\
\hline$>958$ & Extremely rugged & 0 & 0 & 0 & 0 & 0 \\
\hline
\end{tabular}

Table 5. TRI Danger Classes

\begin{tabular}{llll}
\hline TRI & Name of the class & Normalized Score $(\%)$ & Danger class \\
\hline $0 \sim 80$ & Level & 57.11 & Very high \\
$81 \sim 116$ & Nearly Level & 2.79 & No danger \\
$117 \sim 161$ & Slightly rugged & 2.63 & No danger \\
$162 \sim 239$ & Intermediately rugged & 10.25 & Moderate \\
$240 \sim 497$ & Moderately rugged & 26.66 & Very high \\
$498 \sim 958$ & Highly rugged & 0.56 & No danger \\
$>958$ & Extremely rugged & 0 & No danger \\
\hline
\end{tabular}

Table 6. Fire Hotspots Occurred in Different Slopes

\begin{tabular}{llllll}
\hline Slope (degrees) & Year & 2011 & 2012 & 2013 & 2014 \\
\hline & 2010 & 118 & 275 & 92 & 93 \\
\cline { 2 - 6 }$<=3$ & 221 & 13 & 48 & 23 & 17 \\
$3 \sim 5$ & 135 & 9 & 61 & 18 & 28 \\
$5 \sim 10$ & 116 & 25 & 271 & 26 & 86 \\
$10 \sim 15$ & 176 & 18 & 276 & 47 & 142 \\
$15 \sim 20$ & 183 & 25 & 497 & 48 & 185 \\
$20 \sim 25$ & 192 & 27 & 329 & 67 & 153 \\
$25 \sim 30$ & 160 & 20 & 126 & 23 & 7 \\
$30 \sim 35$ & 91 & 5 & 66 & 2 & 73 \\
$35 \sim 40$ & 26 & 2 & 21 & 2 & 31 \\
$40 \sim 45$ & 14 & 4 & & 10 \\
$>45$ & 9 & & & \\
\hline
\end{tabular}

Ruggedness Index (TRI) provides an objective quantitative measure of topographic heterogeneity and measured from digital elevation model (DEM) (Riley et al., 1999). It is the difference between the values of a cell and the mean of an eight neighborhood surrounding cells. Terrain has been classified into 7 classes: Level, nearly level, slightly rugged, intermediately rugged, moderately rugged, highly rugged and extremely rugged based on TRI values (Riley et al., 1999; Moreno et al., 2004) and the danger levels were assigned according to the procedure followed as in the fuel type danger index. Table 4 shows the number of fire points in different TRI class levels. Percentage mean was calculated for the years 2010 to 2014 as shown in the Table 5 and fire danger classes were assigned based on their normalized score and Figure 4 shows the terrain ruggedness danger index.

\subsection{Topography}

Topography is an essential physiographic factor, which influences the wind speed and behavior and hence, affects the spreading of fire (Rothermel, 1983). Topography is the most stable factor of the fire triangle and easier to predict its influence on other factors weather and fuel. Topographic factors are slope, aspect and elevation.

\subsection{Slope Danger Index (SDI)}

Slope is the main factor in any fire danger analysis due to the fact that fire travels up slope faster than down (Chuvieco and Congalton, 1989; Jaiswal et al., 2002). In general, steeped slopes tend to increase the rate of fire spread as compared with flat surfaces or lower steeped slopes. In this study, historical fire data from 2010 to 2014 have been used to measure the slopes which are more vulnerable to fire. Table 6 shows the fire incidents occurred in different slopes of the study area.

From the table 6 , it is evident that a larger number of fire incidences occurred below 3 degree and minimum above 40 degrees, which is against the general hypothesis for the spread of fire (Chuvieco and Congalton, 1989; Dong et al., 2005; Rathaur, 2005). After the field visit to entire forests of Uttarakhand state, concluded that the higher litter content with driest condi- 
tion and longer time of sunlight received in down the slope were the main cause of the higher incidence of fires, this will support surface fires in the Uttarakhand Himalayas. Accessibility is the main reason for the larger number of fires in the lesser slopes ( $<3$ degrees) as the humans can easily climb and ignite the fires either intentional or unintentional ways. Mean number of fire incidents calculated in each year for the above slope intervals and normalized to determine the fire danger levels. Table 7 shows the danger levels were assigned to the different range of slopes and slope danger index was generated (Figure 5).

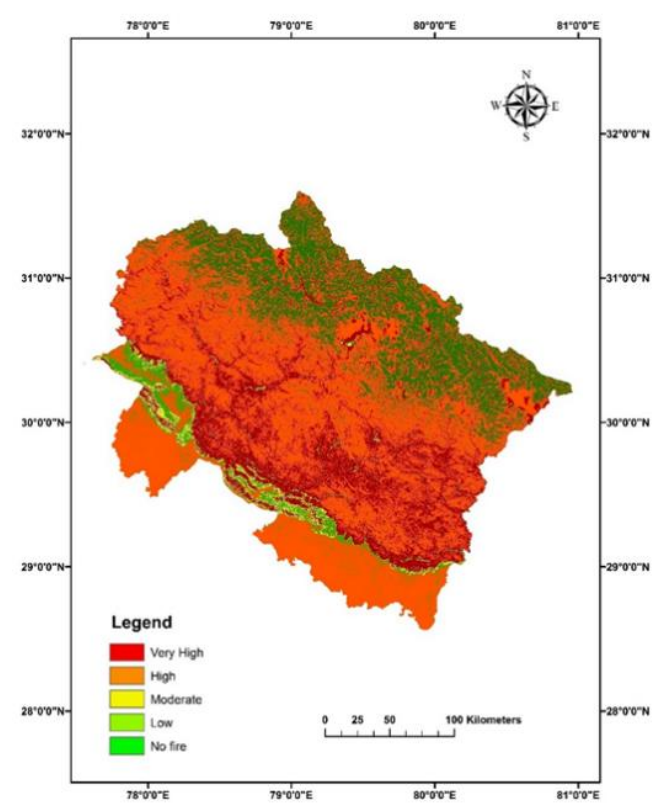

Figure 4. Terrain ruggedness danger index.

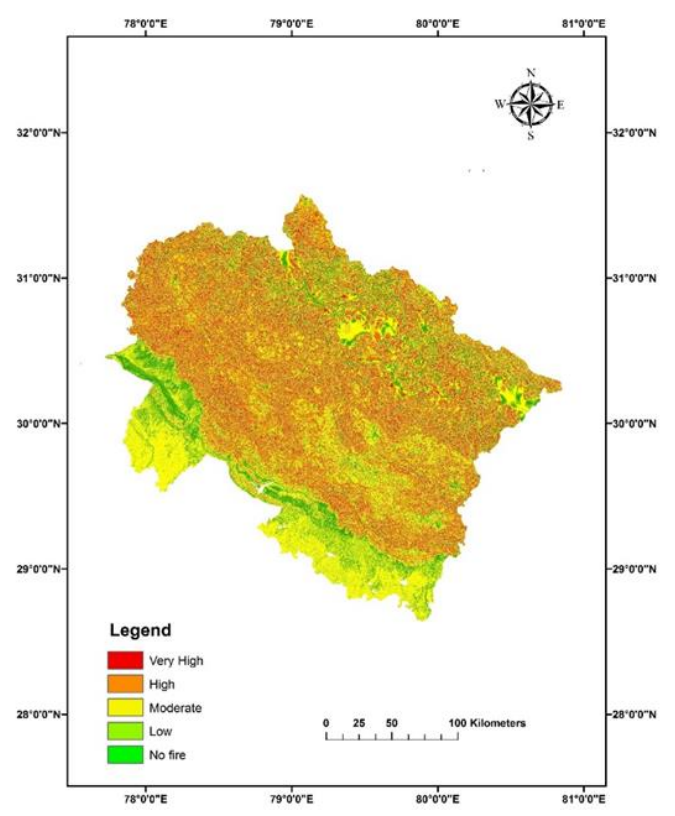

Figure 5. Slope danger index.
Table 7. Fire Danger Levels for Different Range of Slopes

\begin{tabular}{lll}
\hline Slope (Degrees) & Normalized score $(\%)$ & Danger class \\
\hline$<=3$ & 22.08 & Very high \\
$3 \sim 5$ & 5.18 & Low \\
$5 \sim 10$ & 4.62 & No danger \\
$10 \sim 15$ & 10.17 & Moderate \\
$15 \sim 20$ & 10.39 & Moderate \\
$20 \sim 25$ & 15.68 & High \\
$25 \sim 30$ & 15.41 & High \\
$30 \sim 35$ & 10.10 & Moderate \\
$35 \sim 40$ & 3.75 & No danger \\
$40 \sim 45$ & 1.67 & No danger \\
$>45$ & 0.94 & No danger \\
\hline
\end{tabular}

\subsection{Aspect Danger Index (ADI)}

Aspect is the direction the slope faces and it determines the effect of solar radiation, moisture and air temperature (Chuvieco and Congalton, 1989). As the state Uttarakhand is in the Northern Hemisphere, where south facing slopes receive more solar radiation which results in lower humidity, less moisture and higher fuel temperatures creating suitable condition for initiation of forest fires. Fire incidents from 2010 to 2014 were used to compute the Aspect Danger Index. Aspect map of Uttarakhand was generated from the ASTER GDEM and categorized into 10 classes viz. flat $(-1)$, North $(0 \sim 22.5)$, Northeast (22.5 67.5), East (67.5 112.5) Southeast (112.5 157.5), south (157.5 202.5), southwest (202.5 247.5), west (247.5 $\sim 292.5)$, northwest $(292.5 \sim 337.5)$ and north $(337.5 \sim 360)$. Total number of fire incidents in each of the aspect classes were extracted for the period $2010 \sim 2014$ during fire season. Table 8 represents the total number of fire incidents in different aspect classes.

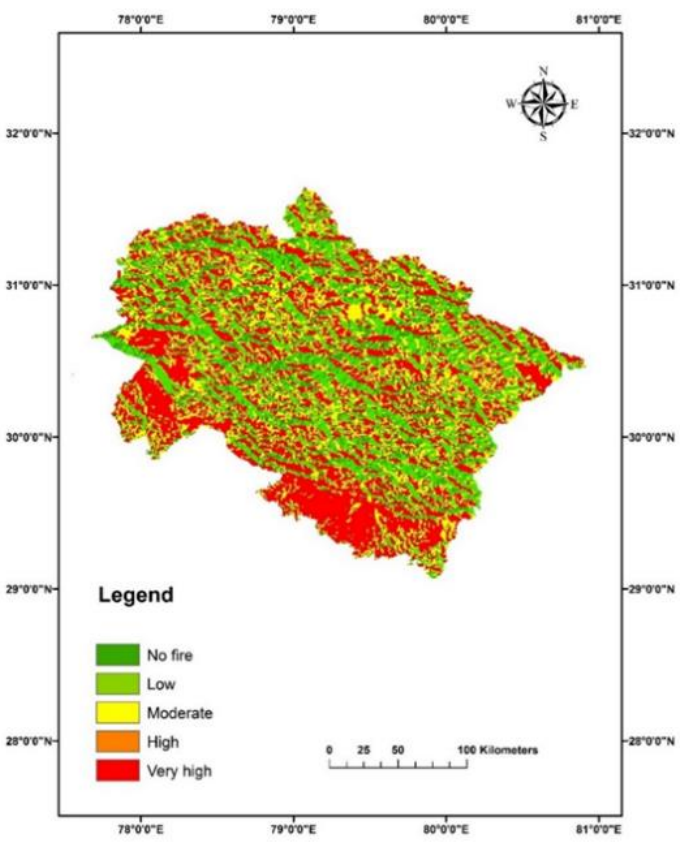

Figure 6. Aspect danger index. 
Table 8. Fire Incidents in Different Aspects

\begin{tabular}{|c|c|c|c|c|c|c|}
\hline \multirow[t]{2}{*}{ S. No. } & \multirow[t]{2}{*}{ Name of the aspect classes } & \multicolumn{5}{|l|}{ Year } \\
\hline & & 2010 & 2011 & 2012 & 2013 & 2014 \\
\hline 1 & Flat & 0 & 0 & 0 & 0 & 0 \\
\hline 2 & North & 40 & 8 & 115 & 9 & 53 \\
\hline 3 & Northeast & 120 & 12 & 250 & 21 & 89 \\
\hline 4 & East & 100 & 20 & 271 & 16 & 113 \\
\hline 5 & Southeast & 119 & 74 & 501 & 72 & 199 \\
\hline 6 & South & 340 & 74 & 501 & 72 & 199 \\
\hline 7 & Southwest & 346 & 75 & 495 & 105 & 169 \\
\hline 8 & west & 142 & 27 & 233 & 36 & 103 \\
\hline 9 & Northwest & 79 & 6 & 173 & 31 & 67 \\
\hline 10 & North & 34 & 6 & 78 & 6 & 40 \\
\hline
\end{tabular}

The total number of fire points were normalized into 1 to 100 to estimate which aspect class was more susceptible to fire and the mean of normalized score was computed. Table 9 shows the mean normalized score and the corresponding danger levels and Figure 6 shows the generated aspect danger index.

\subsection{Elevation Danger Index (EDI)}

The variable elevation is considered as an important factor of forest fire because it influences the precipitation and temperature. The weather is hot and moist in the sub-Himalayan zone and in river valleys below $600 \mathrm{~m}$ in elevation whereas the climate becomes sub-tropical up to the elevation of $1200 \mathrm{~m}$. Elevations of Uttarakhand were categorized into different ranges to know the vulnerability of forest fires. Table 10 shows the fire incidents occurred in different elevation ranges of the study area.

Table 9. Aspect Danger Index

\begin{tabular}{llll}
\hline S. No. & $\begin{array}{l}\text { Aspect } \\
\text { degree }\end{array}$ & $\begin{array}{l}\text { Mean normalized } \\
\text { score }(\%)\end{array}$ & Danger class \\
\hline 1 & Flat & 0 & No danger \\
2 & North & 3.82 & No danger \\
3 & Northeast & 7.95 & Low \\
4 & East & 8.62 & Low \\
5 & Southeast & 11.29 & Moderate \\
6 & South & 23.53 & Very high \\
7 & Southwest & 25.06 & Very high \\
8 & west & 10.5 & Moderate \\
9 & Northwest & 6.39 & Low \\
10 & North & 2.82 & No danger \\
\hline
\end{tabular}

From Table 10, it was clear that maximum number of fires occurred in the elevation ranges from 0 to $1200 \mathrm{~m}$ above mean sea level, followed by elevation ranges from 1200 to $1800 \mathrm{~m}$ and less or very few fires in the ranges from 2700 to $3200 \mathrm{~m}$, no fires in the altitudes above $3200 \mathrm{~m}$. After the field visit, it was concluded that the anthropogenic activities were the main cause of occurrence of highest fire incidences in the elevations below $600 \mathrm{~m}$ and 600 to $1200 \mathrm{~m}$; presence of pine forests are the responsible for highest number of fires in the elevation ranges 1200 to $2400 \mathrm{~m}$. There are lesser or no fires in the elevations greater than $2700 \mathrm{~m}$ because the climate is cold frigid. Number of fire points in each year were normalized into 1 to 100 and mean of all 5 years were calculated and danger levels were assigned based on the value. Table 11 represents the danger levels assigned to different elevation ranges and the mean normalized value. Figure 7 shows the elevation danger index.

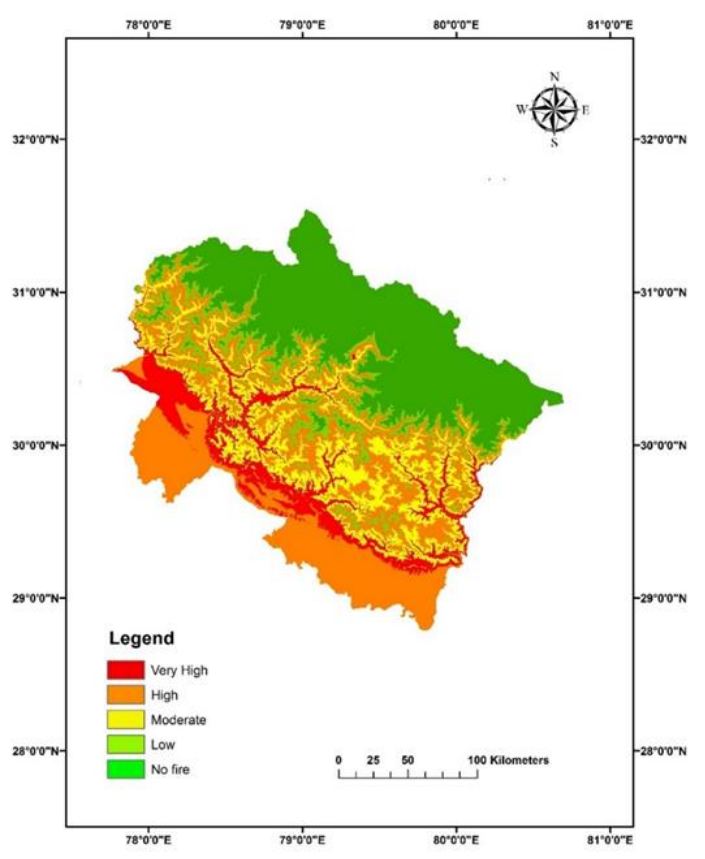

Figure 7. Elevation danger index.

\section{Results and Discussion}

The studies carried out by various researchers (Chuvieco and Congalton, 1998; Dong and Rathur, 2005; Orozco, 2008; Heikkila, 2010), danger levels were assigned randomly to each factor based on the hypothesis of forest fire spread without consideration of characteristics of the study area and historical fire records. In this study, danger levels were assigned to each parameter based on the historical occurrence of fire data. So, Analytical Hierarchical Process (AHP) method was used to calculate the forest fire risk in the above mentioned studies. In 
Table 10. Fire Hotspots Occurred in Different Elevation Ranges

\begin{tabular}{|c|c|c|c|c|c|}
\hline \multirow[t]{2}{*}{ Elevation } & \multicolumn{5}{|l|}{ Year } \\
\hline & 2010 & 2011 & 2012 & 2013 & 2014 \\
\hline $0 \sim 600$ & 308 & 53 & 308 & 68 & 148 \\
\hline $601 \sim 1200$ & 546 & 130 & 786 & 148 & 296 \\
\hline $1201 \sim 1800$ & 190 & 32 & 212 & 28 & 166 \\
\hline $1801 \sim 2400$ & 192 & 28 & 242 & 77 & 312 \\
\hline $2401 \sim 2700$ & 71 & 21 & 158 & 5 & 42 \\
\hline $2701 \sim 3200$ & 17 & 3 & 9 & 0 & 0 \\
\hline$>3200$ & 0 & 0 & 0 & 0 & 0 \\
\hline
\end{tabular}

this study, weights were assigned to each parameter based on the historical fire occurrence. Therefore, Static Fire Danger Index (SFDI) was developed by combining all the five individual danger indices i.e. LULC danger index, Terrain Ruggedness Danger Index, Slope danger index, Aspect danger index and Elevation danger index as each individual index was generated based on the historical fire incidents and the field observation.

Therefore, Static Fire Danger Index (SFDI) was calculated by combining all the five individual danger indices i.e. LULC danger index, Terrain Ruggedness Danger Index, Slope danger index, Aspect danger index and Elevation danger index and Equation 1 shows the calculation of SFDI:

$S F D I=L U L C D I+T R D I+S D I+A D I+E D I$

The SFDI has been categorized into fire danger classes viz. no fire, Low, Moderate, High and Very high based on the Table 12.

Table 11. Elevation Danger Index

\begin{tabular}{lll}
\hline Elevation $(\mathrm{m})$ & Mean of normalized score $(\%)$ & Danger class \\
\hline $0 \sim 600$ & 19.46 & High \\
$601 \sim 1200$ & 42.37 & Very high \\
$1201 \sim 1800$ & 12.90 & Moderate \\
$1801 \sim 2400$ & 19.02 & High \\
$2401 \sim 2700$ & 5.67 & Low \\
$2701 \sim 3200$ & 0.59 & No danger \\
$>3200$ & 0 & No danger \\
\hline
\end{tabular}

Table 12. SFDI Danger Classes

\begin{tabular}{lll}
\hline S. No & SFDI & Danger level \\
\hline 1 & $<=5$ & No fire \\
2 & $6 \sim 10$ & Low \\
3 & $11 \sim 15$ & Moderate \\
4 & $16 \sim 20$ & High \\
5 & $>20$ & Very high \\
\hline
\end{tabular}

MODIS TERRA and AQUA active fire hotspot data (MCD14) during the fire season of 2015, 2016 and 2017 were downloaded from the FIRMS website and has been used to estimate the accuracy of the SFDI. MODIS active fire hotspots have been used for validating index the fire danger model in various studies as a proxy for the actual occurrence of fires (Chuvieco et al., 2008; Vadrevu et al., 2010; Maeda et al., 2011; Adab et al., 2013; Eskandari and Chuvieco, 2015). Similarly, in the present study, MODIS active fire product MCD14 has been used for the validation for SFDI. Figures $8 \sim 10$ showing the map of static fire danger index overlaid with active fire data of 2015 , 2016 and 2017.

In most of the studies, accuracy was estimated based on the number of fire incidents fell in different fire danger classes (Vadrevu et al., 2009; Maeda et al., 2011; Adab et al., 2013; Sitanggang et al., 2013; Eskandari and Chuvieco, 2015; Akhtar and Hussain, 2011; Mitri et al., 2017). They counted the number of fires fell in each fire danger classes and the classes "Low" and "Very low" classes were considered as "no fire is predicted"; the classes "High", "Very high" and "Extreme" classes were considered as "a fire is predicted". However, in this study, fires fell in "No fire danger", "Low" and "Moderate" were considered as fire is not predicted and otherwise predicted.

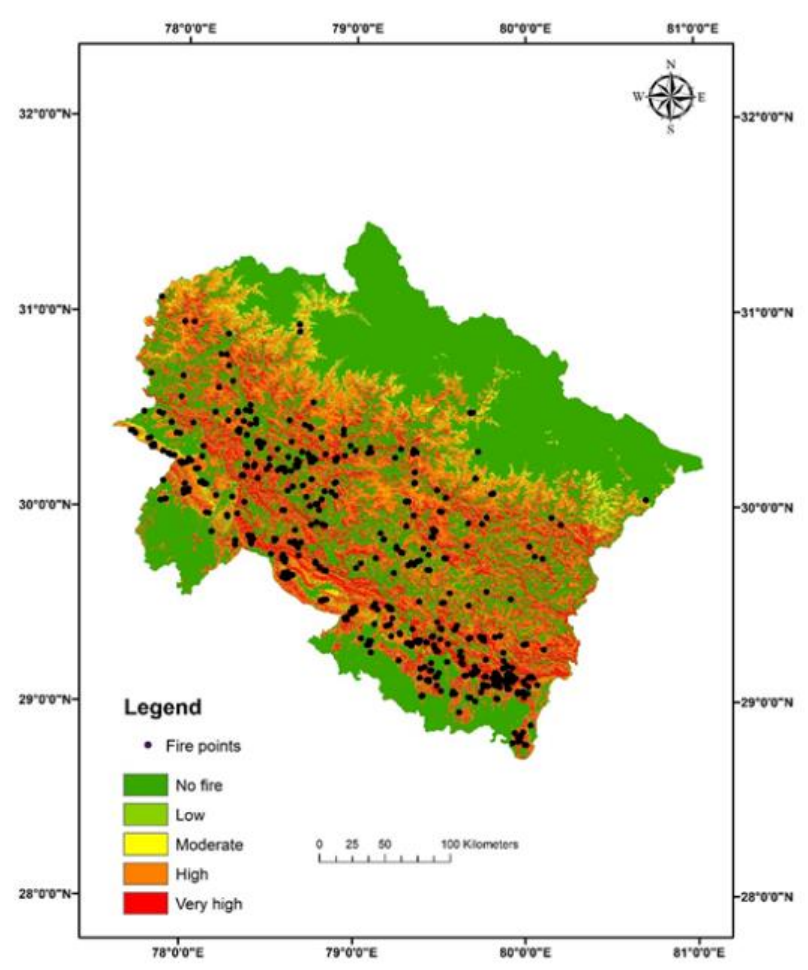

Figure 8. Static fire danger index overlaid with fire hotspots of 2015 . 


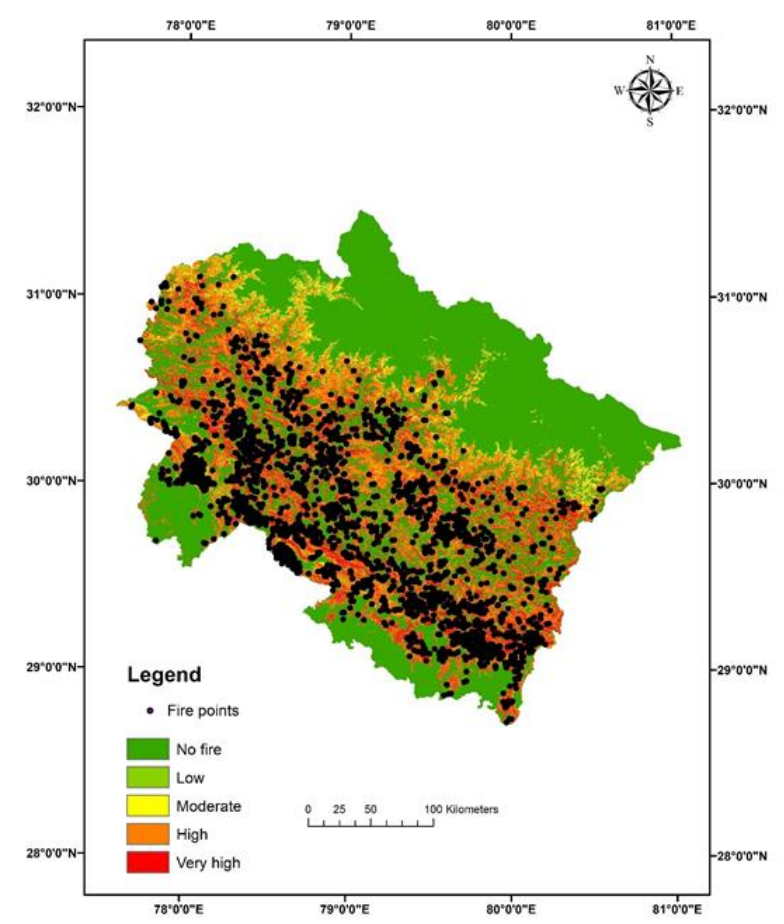

Figure 9. Static fire danger index overlaid with fire hotspots of 2016 .

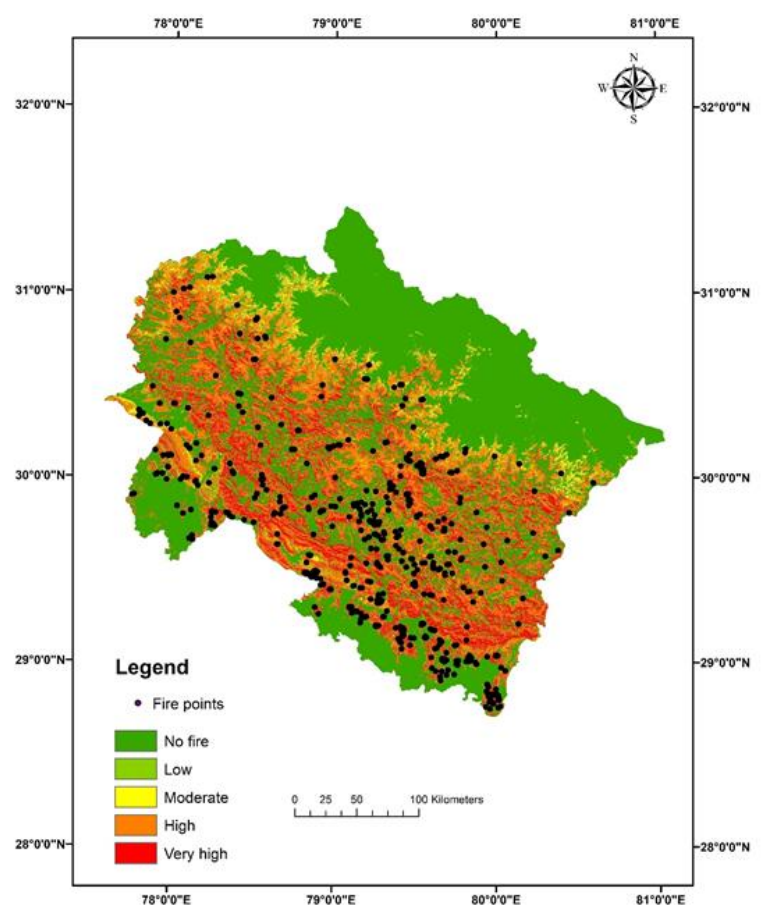

Figure 10. Static fire danger index overlaid with fire hotspots of 2017.

Receiver Operating Characteristic (ROC) technique is used for the effective validation of developed SFDI. ROC represents the probability curve while, the area under ROC curve
(AUC) represents the degree of separability between classes and also expresses the quality of a prediction model (Yesilnacar and Topal, 2005). If the value of AUC is close to 1 , then the result of model is excellent, where as the result of model is fairer when the AUC is near to 0.5.

(a) ROC curve for the year 2015

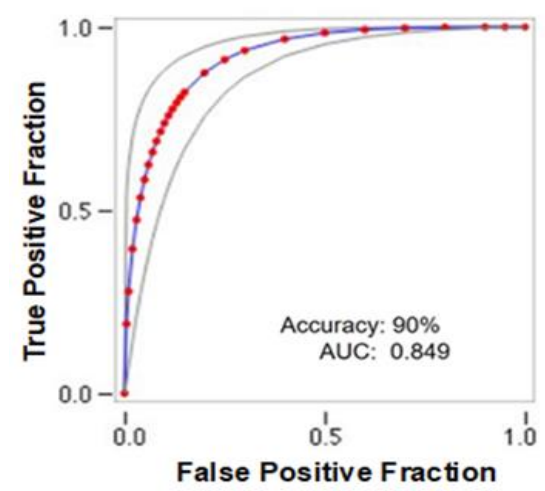

(b) ROC curve for the year 2016

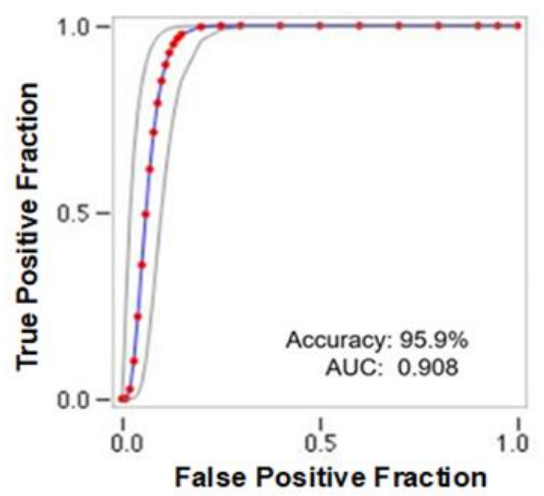

(c) ROC curve for the year 2017

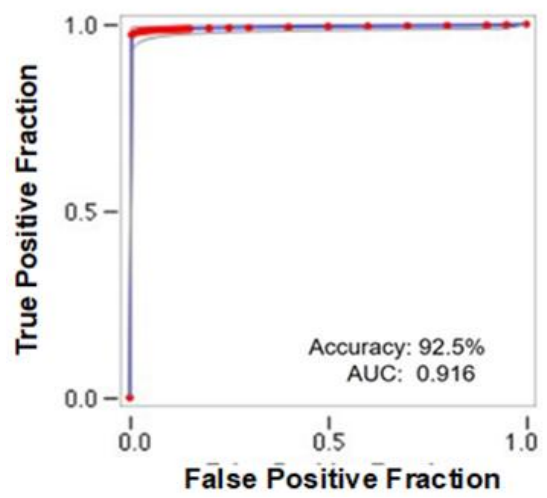

Figure 11. ROC curves and AUC of SFDI for the years (a) 2015, (b) 2016, and (c) 2017.

From the Figure 11, it was evident that that accuracy is $90 \%, 95.9 \%, 92.5 \%$ in the years 2015, 2016 and 2017 respectively. It was also observed that, AUC is ranging from 0.84 to 0.916 i.e. the model accuracy is very good. The SFDI is generated by using the satellite derived datasets with a spatial resolution of $1 \mathrm{~km}$ and will generate every year with the updated 
MODIS land cover type product (MCD12Q1). Therefore, the Static Fire Danger Index accurately represents the distribution of fire danger over the study area.

\section{Conclusions}

Static fire danger rating index has been developed from the static parameters such as fuel type, slope, aspect, elevation, Terrain rugged index and danger levels have been assigned based on the historical fire occurrence data. MODIS TERRA and AQUA Land cover type (MCD12Q1) and ASTER GDEM have been used in this study. Fuel type danger index was generated from the IGBP product, which was extracted from the datasets MCD12Q1. ASTED GDEM was used for the generation of Ter-rain Ruggedness Danger Index, Aspect Danger Index, Slope Danger Index, Elevation Danger Index based on the historical fire location data as well as ground investigation. The SFDI was computed by combining all the individual indices and validated with the fire incidents occurred during the years 2015, 2016 and 2017.

Accuracy of SFDI for the years 2015, 2016 and 2017 were $90 \%, 95.9 \%$ and $92.5 \%$ respectively and AUC is ranging from 0.84 to 0.916 i.e. accuracy of the developed SFDI is very good enough to predict the forest fire danger spread based on the static characteristics of the study area. The developed methodology is useful to generate SFDI every year by using the updated MODIS land cover type dataset MCD12Q1 with a spatial resolution of $1 \mathrm{~km}$. Thus, Static Fire Index is useful to understand the spatial pattern of fire occurrence in the study area and used to determine areas of high fire danger due to the fundamental conditions that leads to fire occurrence. The present study discusses about the calculation of static fire danger index based on the static factors responsible for fire danger. In future, Static fire danger index will be integrated with the dynamic fire danger index to generate the forest fire danger index of the study area so that fire danger maps can be disseminated to the forest officials to suppress the forest fires.

Acknowledgments. First author is grateful to Department of Science and Technology (DST), New Delhi, for awarding INSPIRE fellowship. Authors would be thankful to Director IIRS, Dr. Prakash Chauhan for their encouragement. Authors also acknowledge Dr. Ramachandra Prasad, Lab for Spatial Informatics, IIIT, Hyderabad for his suggestions and support throughout research. The authors acknowledge the MODIS Science team for the Science Algorithms, the Processing Team for producing MODIS data, and the GES DAAC MODIS Data Support Team for making MODIS data available to the user community, NASA REVERB team and FIRMS websites for free MODIS TERRA datasets and Fire data.

\section{References}

Adab, H., Kanniah, K.D., and Solaimani, K. (2013). Modeling forest fire risk in the northeast of Iran using remote sensing and GIS techniques. Natural Hazards, 65(3), 1723-1743. https://doi.org/ 10.1007/s11069-012-0450-8

Babu, K.V.S., Roy, A., and Prasad, P.R. (2016a). Forest fire risk modeling in Uttarakhand Himalaya using TERRA satellite datasets. European Journal of Remote Sensing, 49(1), 381-395. https://doi. org/10.5721/EuJRS20164921
Babu, K.S., Roy, A., and Prasad, P.R. (2016b). Developing the static fire danger index using geospatial technology. In 2016 2nd International Conference on Contemporary Computing and Informatics (IC3I), (pp. 558-563). IEEE. https://doi.10.1109/IC3I. 2016. 7918026

Babu, K. V. S. and Roy, A. (2019). Automation of Forest Fire Danger Index from the Near Real Time Satellite Datasets. Journal of Environmental Informatics Letters, 2(1), 1-9. https://doi.10.3808 /jeil.201900015

Babu, K.V.S., Kabdulova, G., and Kabzhanova, G. (2019). Developing the Forest Fire Danger Index for the Country Kazakhstan by Using Geospatial Techniques. Journal of Environmental Informatics Letters, 1, 48-59. https://doi.10.3808/jeil. 201900006

Belward, A.S., Estes, J.E., and Kline, K.D. (1999). The IGBP-DIS Global 1-km Land Cover Data Set DISCover: A Project Overview. Photogrammetric Engineering and Remote Sensing, 65(9), 10131020.

Butler, B.J., Tyrrell, M., Feinberg, G., VanManen, S., Wiseman, L., and Wallinger, S. (2007). Understanding and reaching family forest owners: Lessons from social marketing research. Journal of Forestry, 105(7), 348-357. https://doi.org/10.1093/jof/105.7.348

Chan, J.W. and Tong, T. K. (2007). Multi-criteria material selections and end-of-life product strategy: Grey relational analysis approach. Materials \& Design, 28(5), 1539-1546. https://doi.org/10.1016/j. matdes.2006.02.016

Chuvieco, E. (2008). Satellite observation of biomass burning. Earth Observation of Global Change, Springer, Dordrecht, 109-142.

Chuvieco, E. and Congalton, R.G. (1989). Application of remote sensing and geographic information systems to forest fire hazard mapping. Remote Sensing of Environment, 29(2), 147-159. https: //doi.org/10.1016/0034-4257(89)90 023-0

Cochrane, M.A. (2003). Fire science for rainforests. Nature, 421(6926), 913-919. https://doi.org/10.1038/nature01437

Deeming, J.E., Burgan, R.E., and Cohen, J.D. (1977). The National Fire-Danger Rating System, 1978, Intermountain Forest and Range Experiment Station, Forest Service, US Department of Agriculture.

Dong, X., Li-min, D., Guo-fan, S., Lei, T., and Hui, W. (2005). Forest fire risk zone mapping from satellite images and GIS for Baihe Forestry Bureau, Jilin, China. Journal of Forestry Research, 16(3), 169-174. https://doi.org/10.1007/ BF02856809

NASA's Distributed Active Archive Centers (DAACs). Earthdata. https://earthdata.nasa.gov

Eskandari, S., and Chuvieco, E. (2015). Fire danger assessment in Iran based on geospatial information. International Journal of Applied Earth Observation and Geoinformation, 42, 57-64. https://doi.org/ 10.1016/j.jag. 2015.05.006

The University of Maryland. Fire Information for Resource Management System. https://firms.modaps.eosdis.nasa. gov/

Friedl, M.A., Sulla-Menashe, D., Tan, B., Schneider, A., Ramankutty, N., Sibley, A., and Huang, X. (2010). MODIS Collection 5 global land cover: Algorithm refinements and characterization of new datasets. Remote Sensing of Environment, 114 (1), 168- 182. https:// doi.org/10.1016/ j.rse.2009.08.016

Gai, C., Weng, W., and Yuan, H. (2011). GIS-based forest fire risk assessment and mapping. 2011 Fourth International Joint Conference on Computational Sciences and Optimization (CSO), (pp. 1240-1244). IEEE. https://doi.10.1109/CSO.2011.140

Heikkilä, T.V., Grönqvist, R., and Jurvélius, M. (2010). Wildland Fire Management: Handbook for Trainers. FAO.

Hély, C., Bergeron, Y., and Flannigan, M.D. (2000). Effects of stand composition on fire hazard in mixed-wood Canadian boreal forest. Journal of Vegetation Science, 11(6), 813-824. https://doi.org/10. $2307 / 3236551$

ISFR, (2011). State of Forest Report. Forest Survey of India, Dehradun. pp. 26 
Jaiswal, R.K., Mukherjee, S., Raju, K.D., and Saxena, R. (2002). Forest fire risk zone mapping from satellite imagery and GIS. International Journal of Applied Earth Observation and Geoinformation, 4(1), 1-10. https://doi.org/10.1016/S03032434(02) 00006-5

Kushla, J.D. and Ripple, W.J. (1997). The role of terrain in a fire mosaic of a temperate coniferous forest. Forest Ecology and Management, 95(2), 97-107. https://doi.org/10.1016/S03781127(97) 82929-5

Babu K.V.S., and Roy, A. (2016). Forest fire danger index based on modifying Nesterov Index, fuel, and anthropogenic activities using MODIS TERRA, AQUA and TRMM satellite datasets. In Land Surface and Cryosphere Remote Sensing III, International Society for Optics and Photonics, 9877, 98771A. https://doi.org/10.1117/ 12.2222738

The U.S. Geological Survey (USGS) and the National Aeronautics and Space Administration (NASA). Land Processes Distributed Active Archive Center. https://lpdaac.usgs.gov/productsearch/? Collection $=$ Combined + MODIS \& collections $=$ Terra + MODIS \& collections $=\mathrm{A}$ qua+MODIS\& view=list.

Maeda, E.E., Arcoverde, G.F., Pellikka, P.K., and Shimabukuro, Y.E. (2011). Fire risk assessment in the Brazilian Amazon using MODIS imagery and change vector analysis. Applied Geography, 31(1), 7684. https://doi.org/10.1016/j.apgeog.2010.02.004

Måren, I.E., Karki, S., Prajapati, C., Yadav, R.K., and Shrestha, B.B. (2015). Facing north or south: Does slope aspect impact forest stand characteristics and soil properties in a semiarid trans-Himalayan valley? Journal of Arid Environments, 121, 112-123. https://doi.org/ 10.1016/j.jaridenv.2015.06.004

McArthur, A.G. (1967). Fire behaviour in eucalypt forests.

Mitri, G., Saba, S., Nader, M., and McWethy, D. (2017). Developing Lebanon's fire danger forecast. International Journal of Disaster Risk Reduction, 24, 332-339. https://doi.org/10.1016/j.ijdrr.2017. 06.028

Moreno, M., Torres, M., Levachkine, S., and Quintero, R. (2004). GIS - application to make geomorphometric analysis in raster data. WIT Transactions on Information and Communication Technologies, 32, 10. https://doi.10.2495/MIS040031

Mukhopadhyay, D. (2001). Forest Fires in Uttaranchal: Issues in Prevention and Control. Economic and Political Weekly, 36(37), 3510-3512. https://www.jstor.org/stable/4411110

Negi, S.S. (1986). A handbook of Forestry - International Book Distributors.

Orozco, S.J., Hussin, Y.A., Weir, M.J.C., and Mas, J.F. (2009). Modeling fire hazard and control for Michoacán state, Mexico. EOGC 2009: Proceedings of the 2nd International Conference on Earth Observation for Global Changes, May 25-29, 2009, Chengdu, Sichuan, China. pp. 2148-2158.

Pyne, S.J., Andrews, P.L., and Laven, R.D. (1996). Introduction to Wild Land Fire. Second edition, John Wiley \& sons. pp. 808.

Raison, J. (2005). Changes in Flammability of Vegetation in Relation to Fire Frequency: Fuel Dynamics after Prescribed Fire and Wildfire in Forests of ACT. Final report on research project funded by the Australian Flora Foundation. Final report on research project funded by the Australian Flora Foundation. (http://www.aff.org.au /Raison flammability_final. pdf).
Rathaur, S., Kushwaha, S.P.S., and Hussin, Y.A. (2006). Fire risk assessment for tiger preybase in Chilla range and vicinity, Rajaji national park, India using remote sensing and GIS. ACRS 2006: Proceedings of the 27th Asian Conference on Remote Sensing ACRS, 9-13 October, 2006 Ulanbaatar, Mongolia. Bangkok: Asian Association of Remote Sensing (AARS), 2006. 6 p. Asian Association on Remote Sensing.

Riley, J.S., DeGloria, D. S., and Robert E. (1999) A Terrain Ruggedness Index that quantifies topographic heterogeneity. International Journal of Sciences, 5, 1-4.

Roberto B.M., Carlos S.S.J., Guimaraes B.M., Santana O.D.L., Paulo C.R.J., and Lobos M.F. (2010). Forest Fire Alert System: a Geo Web GIS prioritization model considering land susceptibility and hotspots-a case study in the Carajás National Forest, Brazilian Amazon. International Journal of Geographical Information Science, 24(6), 873-901. https://doi.org/10.1080/136588109031 94264

Rothermel, R.C. (1983). How to Predict the Spread and Intensity of Forest and Range Fires. US Department of Agriculture, Forest Service, Intermountain Forest and Range Experiment Station.

Sitanggang, I.S., Yaakob, R., Mustapha, N., and Ainuddin, A.N. (2013). Classification model for hotspot occurrences using spatial decision tree algorithm. Journal of Computer Science, 9(2), 244. https://doi. org/10.3844/jessp.2013. 244.251

Vadrevu, K.P., Eaturu, A., and Badarinath, K. (2010). Fire risk evaluation using multicriteria analysis - a case study. Environmental Monitoring and Assessment, 166(1-4), 223-239. https://doi. org/10.1007/s10661-009-0997-3

Van Wagner, C.E. and Forest, P. (1987). Development and Structure of the Canadian Forest Fireweather Index System. Canada Forest Service, Forestry Technical Report.

Vilar, L., Camia, A., and San-Miguel-Ayanz, J. (2015). A comparison of remote sensing products and forest fire statistics for improving fire information in Mediterranean Europe. European Journal of Remote Sensing, 48(1), 345-364. https://doi.org/10.5721/EuJRS 20154820

Whelan, R.J. (1995). The ecology of fire. Cambridge university press, London.

Wimberly, M.C., Cochrane, M.A., Baer, A.D., and Pabst, K. (2009). Assessing fuel treatment effectiveness using satellite imagery and spatial statistics. Ecological Applications, 19(6), 1377-1384. https: //doi.org/10.1890/ 08-1685.1

Yesilnacar, E. and Topal, T. (2005). Landslide susceptibility mapping: a comparison of logistic regression and neural networks methods in a medium scale study, Hendek region (Turkey). Engineering Geology, 79(3-4), 251-266. https://doi.org/10.1016/j.enggeo.2005. 02.002

Ye, T., Wang, Y., Guo, Z., and Li, Y. (2017). Factor contribution to fire occurrence, size, and burn probability in a subtropical coniferous forest in East China. PloS One, 12(2), e0172110. https://doi.org /10.1371/journal.pone. 0172110

Zhai, L.Y., Khoo, L.P., and Zhong, Z.W. (2009). Design concept evaluation in product development using rough sets and grey relation analysis. Expert Systems with Applications, 36(3), 70727079. https://doi.org/10.1016/j. eswa.2008.08.068 